\title{
Fine root mortality under severe drought reflects different root distribution of Quercus robur and Ulmus laevis trees in hardwood floodplain forests
}

\author{
Anastasia Leonova $^{1}\left[\right.$ [ $\cdot$ Adrian Heger ${ }^{2} \cdot$ Lizeth K. Vásconez Navas $^{2} \cdot$ Kai Jensen $^{1} \cdot$ Christoph Reisdorff $^{1}$
}

Received: 30 July 2021 / Accepted: 1 February 2022 / Published online: 23 February 2022

(c) The Author(s) 2022

\begin{abstract}
Key message Extremely high fine root mortalities were observed under drought in 2018, increasing fine root mortality in young trees could be explained by differences in root distribution compared to old trees.

Abstract Juvenile trees in floodplains are prone to high mortality leading to a low success in reforestation in these habitats. One of the reasons contributing to high mortality of juvenile trees could be limited water and nutrient uptake due to a high level of fine root mortality, especially during summer droughts on higher terraces of floodplains. Strategies of different tree species in hardwood floodplain forests (HFFs) on keeping fine roots alive are still poorly understood. During the recordbreaking summer drought of 2018, we examined the relationship between tree age and fine root dynamics of Quercus robur and Ulmus laevis along the Elbe River in Germany. Root area index (RAI), live root density (LRD) and relative root mortality (RRM) of young and old $Q$. robur and U. laevis were analysed by taking soil cores three times during the progression of a summer drought. Old oaks had a lower RAI in the upper soil than young oaks, while RAI of elms did not differ between young and old trees. RRM was very high during summer reaching more than $100 \%$ on average. RRM of young trees of both species increased with increasing drought during summer, while RRM of old trees did not change. We argue that differences in the response of RAI between oaks and elms reflect the sink competition between growing deep roots and shallow roots, which is pronounced in oaks due to their characteristic tap root system. Differences in root distribution patterns and the ability to perform hydraulic redistribution may explain the differences in RRM between trees of different species and ages.
\end{abstract}

Keywords Quercus robur L. · Ulmus laevis Pall. · Fine root mortality · Elbe River · Hardwood floodplain forests

\section{Introduction}

Fine roots are of major importance for forest ecosystems (Jackson et al. 1997; Matamala et al. 2003) and they play a significant role for carbon and nitrogen cycling in forests (Edwards and Harris 1977; Hendricks et al. 1993; Jackson et al. 1997; McCormack et al. 2015). Fine roots are also the trees' most important structure for absorbing water and

Communicated by Aspinwall.

Anastasia Leonova

Anastasia.leonova@uni-hamburg.de

1 Institute of Plant Science and Microbiology, Universität Hamburg, Ohnhorststraße 18, 22609 Hamburg, Germany

2 Institute of Soil Science, Center for Earth System Research and Sustainability (CEN), Universität Hamburg, Allende-Platz 2, 20146 Hamburg, Germany nutrients. Therefore, their vitality is crucial for the overall functioning of single trees and of whole ecosystems. However, belowground processes in forests are still poorly understood. This is especially true for hardwood floodplain forests (HFFs), which are biodiversity hotspots in Europe and elsewhere (Tockner and Stanford 2002). Knowledge on fine roots and on factors affecting their dynamics may though be crucial for the future adjustment of forest management of HFFs in times of global warming.

HFFs develop on upper terraces in river valleys. As a consequence, they are only flooded irregularly during (extreme) high water events. In Central Europe, HFFs consist mainly of oaks (Quercus spp.), ashes (Fraxinus spp.) and elms (Ulmus spp.). HFFs are one of the most productive ecosystems, and they provide a number of ecosystem services, including fertile soils, habitat for animals and plants, water retention (Tockner and Stanford 2002) and organic carbon sequestration (Cierjacks et al. 2010; Shupe et al. 2021). However, due 
to agricultural and watercourse regulation, HFFs in Europe have been facing a high level of anthropogenic pressure during the last centuries (Klimo and Hager 2001; Stojanović et al. 2015; Schindler et al. 2016; Machar et al. 2020). Most floodplains in Germany have been converted to agricultural fields or grasslands, others faced a serious alteration of their hydrological regime due to diking. Today, the area of natural HFFs is estimated to be $125 \mathrm{~km}^{2}$, which is less than $1 \%$ of the overall area of floodplains in Germany (Auenzustandsbericht, BfN 2021).

Trees in HFFs are often prone to seasonally contrasting stressors of flooding occurring mainly in winter and spring and drought developing during summer (Gallardo 2003). Drought promotes cell dehydration and water potential reduction, which ultimately result in cell death. Experimental data on the effect of drought on the vitality of fine roots of different trees vary dramatically. For example, under drought stress, fine root vitality of Norway spruce and Japanese cedar was reported to decrease (Konôpka et al. 2007; Gaul et al. 2008), while drought had no clear effect on fine root vitality of Douglas-fir and common oak (Marshall 1986; Van Hees 1997). Drought-induced root mortality varies among different tree species (Pregitzer et al. 1997; Yuan and Chen 2010), tree ages (Kern et al. 2004; Yuan and Chen 2012) and during the growing season (Hendrick and Pregitzer 1996; Gaul et al. 2008). One of the factors explaining the difference between drought-induced root mortality could be hydraulic redistribution (HR). HR is water movement from wet to dry soil compartments via tree conduits that can improve root survival, especially in drought prone top soils (Neumann and Cardon 2012). HR differs significantly between tree species (Hafner et al. 2017) and can occur even under moderate drought. Differences in the extent of HR between tree species can be explained by variation in their sapwood area (Meinzer et al. 2004), transpiration rates (Domec et al. 2012), root conduit size and root hydraulic conductivity (Hafner et al. 2019). Species with greater share of sapwood area, higher transpiration rates, smaller root conduits and, hence, lower root hydraulic conductivity should be less capable to perform HR effectively. In addition, the shape of the root system (e.g., tap roots) and the distribution pattern of fine roots is of great importance for the capacity to perform HR. HR was studied in many ecosystems; however, knowledge on HR in HFFs is still scarce.

Episodes of low summer precipitation are hypothesized to be threatening for fine roots in temperate climates. In European beech stands, a decrease of $42 \%$ in annual precipitation led to a decline in fine root biomass by about one third (Meier and Leuschner 2008). In HFFs, however, shallow ground water levels can increase the water availability for older trees also during episodes of low precipitation. As trees of different species differ in root systems and root distribution patterns, it could be expected that old trees of species with tap roots and the potential to perform HR may be able to reduce drought-induced mortality of their fine roots in dry top soils of HFFs during summer. To better understand what factors influence fine root mortality in HFFs, we investigated fine root dynamics of young and old $U$. laevis and $Q$. robur trees. Roots of mature $Q$. robur are known to reach up to $300 \mathrm{~cm}$ depth, while roots of mature U. laevis do not grow deeper than $180 \mathrm{~cm}$ (Kutschera and Lichtenegger 2002). This means that mature oaks may be able to reach groundwater during times of drought (Thomsen et al. 2020) and that oaks may maintain high fine root vitality in dry top soils during summer by transporting water from deeper and wetter soil layers to the fine roots subjected to drought in the upper $20 \mathrm{~cm}$ of the soil. Furthermore, oaks may invest more resources in the exploration of deep soil layers than elms and consequently have lower fine root biomass in the upper soil. These expectations are tested in this study.

Our study was conducted on floodplains of the Elbe river in Germany during the record-breaking drought of summer 2018 (Deutscher Wetterdienst 2021). This allowed us to observe fine root dynamics under severe and increasing drought during summer. We measured Root Area Index (RAI), Live Root Density (LRD) and Relative Root Mortality (RRM) as proxies for root surface area, live root biomass and root turnover, respectively. Our aim was to understand (i) whether RAI, LRD and RRM differ between $U$. laevis and $Q$. robur, (ii) how RAI, LRD and RRM are affected by tree age and (iii) how RAI, LRD and RRM are changing during the progressive onset of summer drought. We tested the hypotheses that due to differences in root allocation pattern, (H1) elms have higher RAI and LRD than oaks in the top soil, but lower RAI and LRD than oaks in the deeper soil. We further hypothesize that $(\mathrm{H} 2)$ old trees have higher RAI and LRD and lower RRM than young trees. Finally, we hypothesize that $(\mathrm{H} 3)$ due to different species-specific structural preconditions (in terms of different rooting depths) to perform HR, RAI and LRD will decrease and RRM will increase with increasing drought during summer in elms but not in oaks.

\section{Materials and methods}

\section{Study area}

The study was conducted in HFFs at the Middle Elbe River (Northern Germany). The Elbe is one of the major rivers of Europe, with a length of $1112 \mathrm{~km}$, and a mean annual discharge of $681 \mathrm{~m}^{3} / \mathrm{s}$ in Wittenberge (DGJ 2014). The region has subcontinental climate. Mean annual precipitation is $606 \mathrm{~mm}(1988-2017)$ and varied in these 30 years between 417 and $872 \mathrm{~mm}$. In 2018, the year of our study, the summer 
was the second hottest since 1881 and, with an annual precipitation in the region of $328 \mathrm{~mm}$, the second driest since 1911. From May to August, the sum of precipitation was $72 \mathrm{~mm}$ (13.8 mm in May, $26.2 \mathrm{~mm}$ in June, $12.8 \mathrm{~mm}$ in July and $19.5 \mathrm{~mm}$ in August). This was a deviation of $-70 \%$ from the 30-year mean values (Fig. 1a). As a consequence, soil moisture was extremely low and fell below $7 \%$ of usable field capacity ( $\%$ uFC) during summer months of 2018 (Fig. 1b) according to results modelled from meteorological data measured by a weather station located nearby (Lenzen) by the German Weather Service using the agrometeorological model AMBAV (Deutscher Wetterdienst 2021, for model details see Löpmeier 1994). This was $90-100 \%$ lower than 24-year mean values. Lowest soil moisture during summer months were reached in August 2018 with $1.1 \% \mathrm{uFC}$ at a depth of $0-10 \mathrm{~cm}$ and even less than $0.1 \% \mathrm{uFC}$ at a depth of $10-20 \mathrm{~cm}$.

\section{Site description}

Two old (142-144 years) and two young (19-20 years) HFFs with comparable environmental conditions (for coordinates and stand characteristics see Supplementary Table 1, for overview of experimental design see Supplementary Table 2) were selected for the study along the Elbe
River. Tree age was estimated based on tree ring measurements of a dominant tree within the plot (Shupe, personal communication).

\section{Soil characterization}

Soil texture analyses and reference soil group classification was conducted according to Heger et al. (2021). The dominant reference soil groups (IUSS Working Group WRB, 2015) were Fluvic Cambisols in the old HFFs. Young forests were dominated by Arenic Fluvic Cambisols and Gleyic Cambisols.

\section{Fine root analysis}

Within plots of $25 \mathrm{~m} \times 100 \mathrm{~m}$ established at each of the four HFFs, three oaks and three elms were randomly selected. On a radius of $1 \mathrm{~m}$ around each of the selected tree stems, soil samples were taken with a root corer (diameter: $5 \mathrm{~cm}$, height of the soil cylinder: $10 \mathrm{~cm}$, manufacturer: Eijkelkamp) at three random points in two depths $(0-10 \mathrm{~cm}$ and $10-20 \mathrm{~cm})$ successively going down from the top. Sampling took place three times during summer 2018: 22.-30.05. ("early summer"), 02.-05.07. ("mid-summer") and 30.07.-02.08. ("late summer"). To reduce the influence of disturbance due to the prior sampling, a distance of $40 \mathrm{~cm}$ was kept to soil

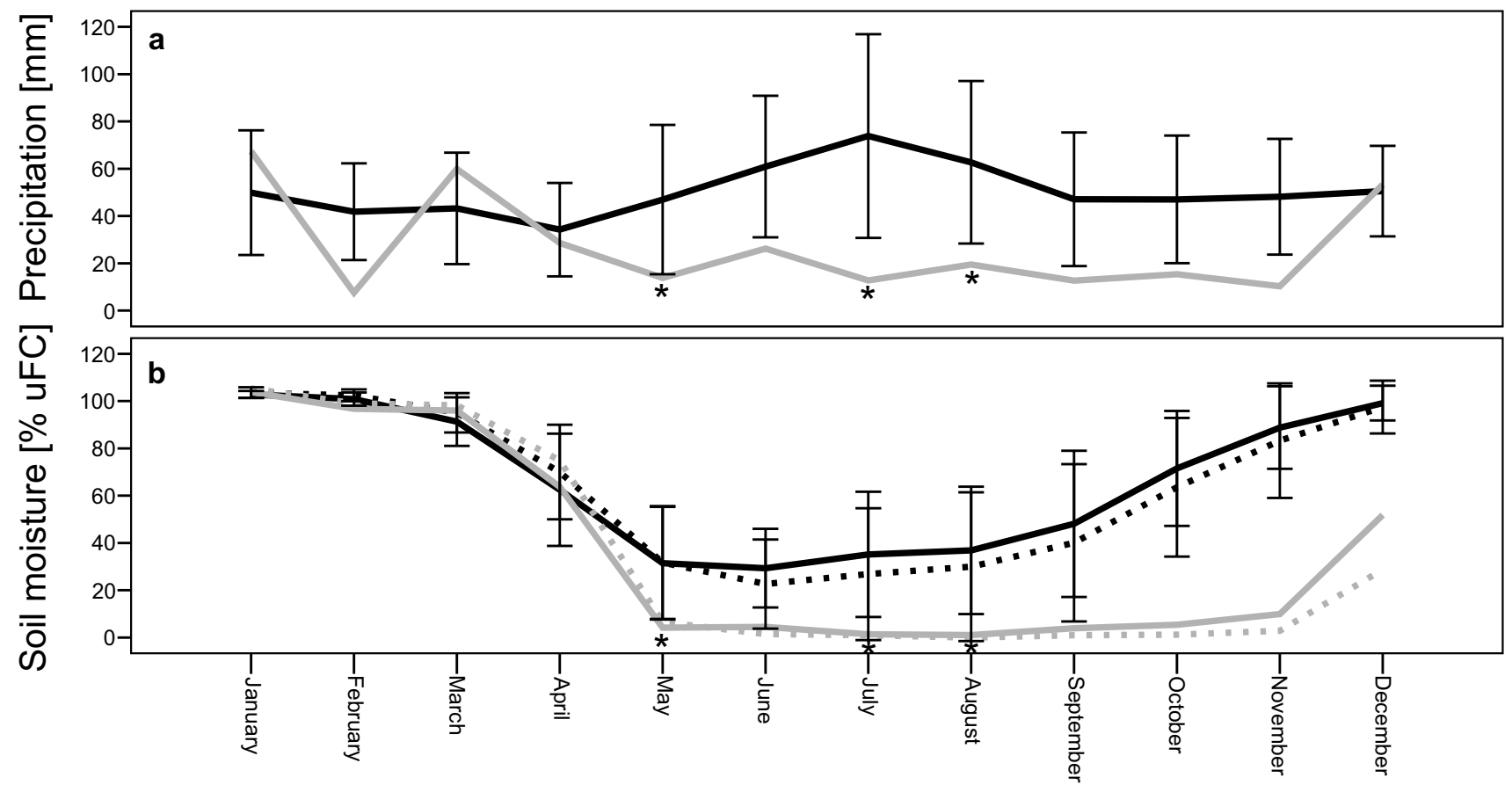

Fig. 1 a Observed values for monthly precipitation [mm] in 2018 (gray line) compared to 30-year mean values (1988-2017; Means \pm SD; black line). Data from Lenzen Weather Station (DWD 2021). b Modelled values for soil moisture [\% of usable field capacity] under grass and sandy loam in 2018 (gray solid line for 0-10 cm depth, gray dashed line for $10-20 \mathrm{~cm}$ depth) compared to 24-year mean values (1994-2017; Means \pm SD; black solid line for 0-10 cm depth, black dashed line for 10-20 cm depth). Data from Lenzen Weather Station (DWD 2021). Asterisks denote sampling dates 
cores taken at the preceding sampling (Richter et al. 2013). Collected soil samples were put into plastic bags (samples from different depths were kept separately) and transported in a cooled box to the laboratory, where they were stored at $+3{ }^{\circ} \mathrm{C}$ until further processing.

In the laboratory, fine roots $(\varnothing<2 \mathrm{~mm})$ were manually separated from the soil using a sieve of $2 \mathrm{~mm}$ mesh size and washed with tap water. Live and dead roots were distinguished under a dissecting microscope. White and flexible roots were classified as alive; dark, and easily breakable roots were recognized as dead (Hertel and Leuschner 2002). To analyse live root surface area, live roots were scanned with an Epson scanner (Expression 1680) at a resolution of 600 dpi. The surface area of the roots was measured using the ImageJ area measuring tool (Rasband, W.S., ImageJ, U. S. National Institutes of Health, Bethesda, Maryland, USA, https://imagej.nih.gov/ij/, 1997-2018). After scanning, live and dead roots were dried for $48 \mathrm{~h}$ at $60{ }^{\circ} \mathrm{C}$ and weighed using a Sartorius Entris 224I-1S balance.

\section{Fine root parameters}

To describe dynamics of fine root quantity during summer, we determined root area index (RAI) as a measure of fine root surface and live root density (LRD) as a measure of fine root biomass. To calculate RAI, live root surface area of each sample was divided by the area of the corer (19.6 $\left.\mathrm{cm}^{2}\right)$. LRD was calculated as dry mass of live roots per soil volume (mg per $100 \mathrm{ml}$ ).

Absolute root mortality (in g dry mass per $\mathrm{g}$ of soil) was calculated using a decision matrix described in McClaugherty et al. (1982) as a difference either in dead biomass or in live biomass between sampling times. Relative root mortality (RRM; in \%) was determined as absolute mortality divided by the live root biomass at the beginning of a sampling interval.

\section{Data analysis}

As soil sand content influences water relations between soil and plants and, as a consequence, plant above- and belowground performance (Bouma and Bryla 2000), we decided to test for a correlation between RAI and LRD and for a dependence of fine root parameters on soil sand content by a regression analysis. The analysis showed that soil sand content had a weak, but significant influence on RAI $\left(R^{2}=0.18\right.$, $p<0.001)$ and LRD $\left(R^{2}=0.29, p<0.001\right)$, and not on RRM $\left(R^{2}=0.002, p>0.05\right)$. To test for differences in RAI and LRD between species, tree ages and time of sampling, Linear Mixed Models (LMMs) were used accounting for tree age (young vs old), tree species (elm vs oak) and time of sampling (early, mid and late summer 2018) as fixed factors and soil sand content as a covariate. The same LMM was used to estimate the influence of above-named factors on RRM, but the soil sand content was not included as a covariate here (as RRM was not affected by sand content, see above). LMM analyses were followed by a Fisher LSD test. Prior to the analyses, the data were tested with Kolmogorov-Smirnov-Test for variance homogeneity and were log-transformed for normalisation. The data were analysed separately for two depths $(0-10 \mathrm{~cm}, 10-20 \mathrm{~cm})$. All analyses were carried out using TIBCO Software Inc. (2017). Statistica, Version 13. http://statistica.io.

\section{Results}

During the summer of 2018, RAI ranged from 0.07 to 4.27 $\mathrm{cm}^{2} \mathrm{~cm}^{-2}$, and LRD from 9 to $956 \mathrm{mg} \mathrm{dm} 100 \mathrm{ml}^{-1}$ in elms and oaks of different ages (see Supplementary Figs. 1 and 2). RAI and LRD were significantly correlated (oak: $R^{2}=0.908, p<0.001$; elm: $\left.R^{2}=0.933, p<0.001\right)$. However, the pronounced difference in slope of the regression lines for different ages of Ulmus laevis (Fig. 2b) shows that old elms have greater root surface area per root biomass than young trees. In oaks, no difference in the slope of the regression

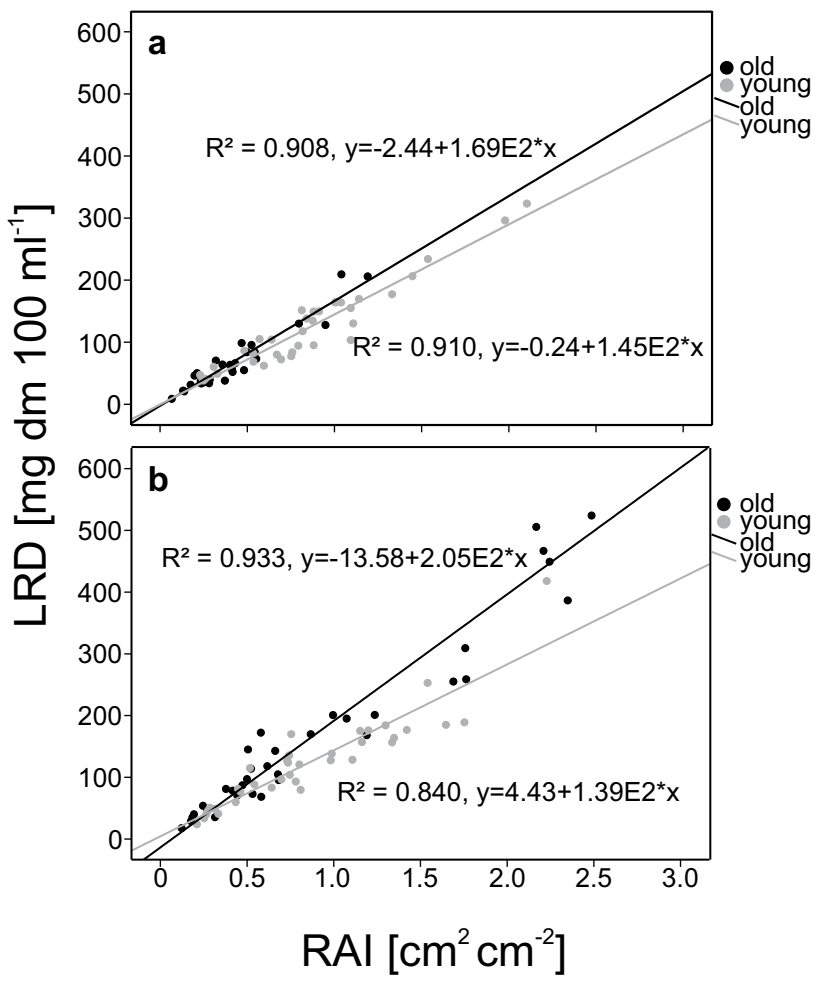

Fig. 2 Relationships between root area index (RAI) and live root density (LRD) of fine roots of old and young trees of Quercus robur (a) and of Ulmus laevis (b) in hardwood floodplain forests at the Middle Elbe river. RAI and LRD were measured at two soils depths in early, mid and late summer of 2018. Outliers were excluded from the graphs 
Table 1 Summary of $F$ values and significance levels from LMMs for dynamics in fine root quantities (RAI, LRD) and fine root mortality (RMM) at two soil depths $(0-10 \mathrm{~cm}$, 10-20 cm) of hardwood floodplain forests at the Middle Elbe river (Northern Germany) during summer 2018

\begin{tabular}{|c|c|c|c|c|c|c|c|}
\hline \multirow[t]{2}{*}{ Depth } & \multirow[t]{2}{*}{ Factor } & \multicolumn{2}{|l|}{ RAI } & \multicolumn{2}{|l|}{ LRD } & \multicolumn{2}{|c|}{ RRM } \\
\hline & & $F$ & $p$ & $F$ & $p$ & $F$ & $p$ \\
\hline \multirow[t]{7}{*}{$0-10 \mathrm{~cm}$} & Age & 3.8 & 0.055 & 0.6 & 0.453 & 2.4 & 0.131 \\
\hline & Species & 15.2 & $<0.001$ & 11.8 & 0.001 & 0.4 & 0.524 \\
\hline & Time & 0.2 & 0.84 & 0.7 & 0.51 & 3.0 & 0.091 \\
\hline & Age $\times$ species & 12.3 & 0.001 & 10.2 & 0.002 & 0.6 & 0.438 \\
\hline & Age $\times$ time & 0.1 & 0.881 & 0.0 & 0.952 & 6.5 & 0.015 \\
\hline & Species $\times$ time & 0.2 & 0.853 & 0.3 & 0.707 & 0.2 & 0.634 \\
\hline & Age $\times$ species $\times$ time & 0.1 & 0.913 & 0.1 & 0.939 & 0.1 & 0.757 \\
\hline \multirow[t]{7}{*}{$10-20 \mathrm{~cm}$} & Age & 9.1 & 0.004 & 1.6 & 0.214 & 0.1 & 0.823 \\
\hline & Species & 0.8 & 0.362 & 1.5 & 0.219 & 4.9 & 0.034 \\
\hline & Time & 1.5 & 0.224 & 1.2 & 0.306 & 0.0 & 1.000 \\
\hline & Age $\times$ species & 2.5 & 0.118 & 3.2 & 0.078 & 0.3 & 0.576 \\
\hline & Age $\times$ time & 0.6 & 0.567 & 0.6 & 0.574 & 4.5 & 0.042 \\
\hline & Species $\times$ time & 3.3 & 0.042 & 2.0 & 0.145 & 1.5 & 0.232 \\
\hline & Age $\times$ species $\times$ time & 0.2 & 0.859 & 0.4 & 0.683 & 0.1 & 0.725 \\
\hline
\end{tabular}

In LMMs, RAI, LRD and RRM were defined as dependent variables and tree age (young vs old), species (oaks, elms), time of sampling (early, mid and late summer) and their interactions as fixed factors

Significant effects are represented in bold

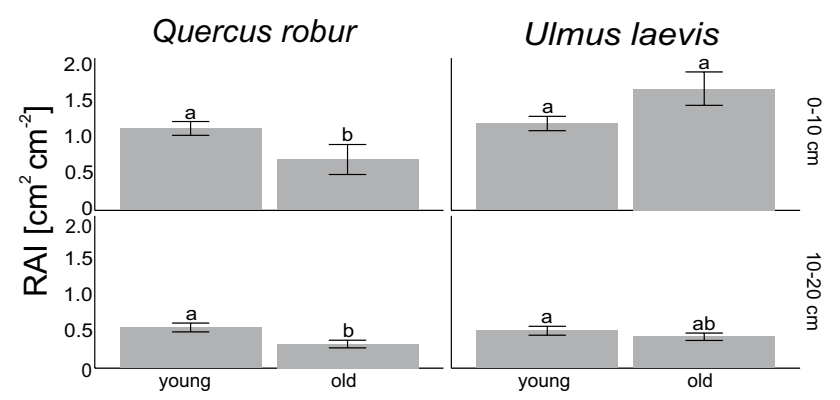

Fig. 3 RAI (root area index) of fine roots of young and old elms and oaks in two soil depths $(0-10$ and $10-20 \mathrm{~cm})$ in hardwood floodplain forests at the Middle Elbe river investigated during summer 2018. Means \pm SE. Different letters denote significant differences between young and old oaks and elms at the same depth $(p<0.05$, Fisher LSD post-hoc test)

lines was found between young and old trees (Fig. 2a), indicating no pronounced age specific difference in the relation between RAI and LRD.

Comparing fine roots of the two species at the depth 0-10 cm, old elms had higher RAI than old oaks, while there was no difference between young trees of the two species (significant interaction age $\times$ species). Young oaks had higher RAI than old oaks at both soil depths, while there was no significant difference between young and old elms (Table 1; Fig. 3). As can be expected from the correlation between RAI and LRD, the LRD roughly confirmed the described pattern of RAI (see Supplementary Figs. 4, 5).

Including the factor "time" into the analysis, the LMM revealed no significant differences in RAI nor in LRD

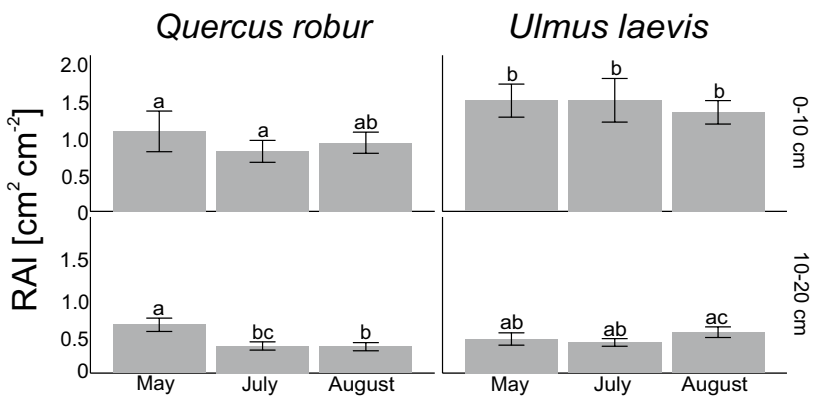

Fig. 4 RAI (root area index) of fine roots of elms and oaks in two soil depths $(0-10$ and 10-20 cm) in early (May), mid (July) and late (August) summer 2018 in hardwood floodplain forests at the Middle Elbe river. Means \pm SE. Different letters denote significant differences between oaks and elms and between sampling times at the same depth $(p<0.05$, Fisher LSD post-hoc test)

between early, mid and late summer in both soil depths for both species. In addition, with one exception no significant interaction with the factor "time" was observed: Only for RAI, a significant interaction of species and time was found at the depth $10-20 \mathrm{~cm}$. Here, RAI significantly decreased during summer in oaks, while RAI of elms did not change (Table 1; Fig. 4). However, the latter result does not oppose the general observation that RAI and LRD overall remained nearly constant and showed no pronounced decrease with increasing drought in summer 2018.

This constant fine root quantity throughout the summer was obviously not due to root survival, as RRM reached over 100\% on average (Fig. 5 and Supplementary Fig. 3). This 


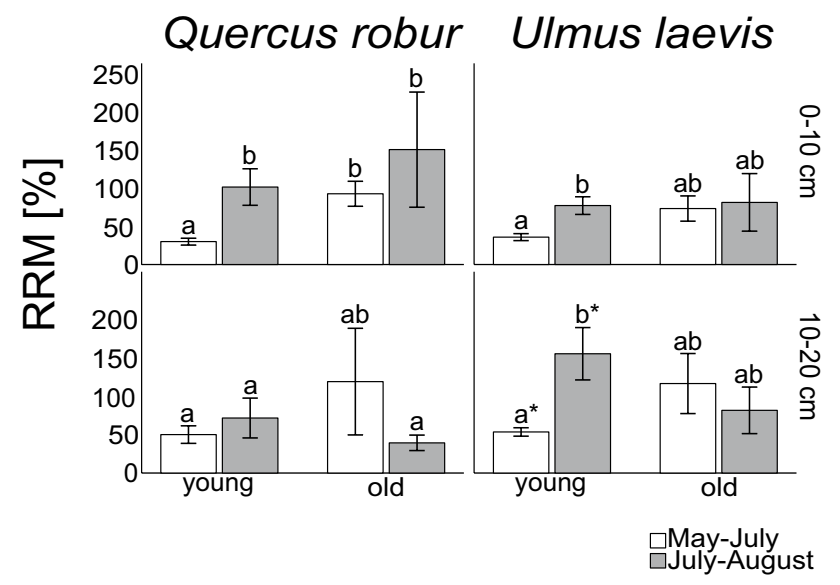

Fig. 5 RRM (relative root mortality) for oaks and elms in two soil depths $(0-10$ and $10-20 \mathrm{~cm})$ of hardwood floodplain forests at the Middle Elbe river during summer 2018. Means \pm SE. Different letters denote significant differences between young and old oaks and elms at the same depth $(p<0.05$, Fisher LSD post-hoc test). Different letters with asterisks denote marginally significant differences $(p=0.06)$

means that at the actual sampling date more dead roots have been found than living roots at the preceding sampling date. This indicates that fine root quantity was maintained rather by the formation of new roots, which compensated the high losses due to extreme soil drought.

In young trees, RRM overall increased during the summer in both depths. At the depth 10-20 cm, however, RRM of young elms showed a threefold increase (from about 50\% to more than 150\%), while RRM of young oaks in this depth did only increase slightly and non-significantly (Fig. 5). RRM of old trees did not significantly change during the summer, but partly showed high variation among replicate trees.

\section{Discussion}

Our first hypothesis was partly confirmed: elms had higher RAI and LRD than oaks, but this was only pronounced in old trees. Our second hypothesis was also partly confirmed: old oaks had lower RAI and LRD than young oaks, but old elms had higher RAI and LRD than young elms in the top soil. Our third hypothesis was not confirmed: RAI and LRD were not decreasing during summer with progressing drought. RRM showed a complex pattern that we are discussing below.

\section{Trees showed rapid fine root turnover with RRM rates of $50-100 \%$}

Obviously, the record-breaking drought of summer 2018 had fatal consequences for fine root vitality, since we found high mortality rates of 50 to $100 \%$ in HFFs. However, even under the extreme stress in 2018, the quantity of fine roots remained constant, meaning that nearly all fine roots lost through mortality were replaced by newly formed roots upon the next sampling. This ecological strategy is known as the "fast-strategy" (Reich 2014) and was also shown in Fagus sylvatica during a drought in 2003 (Nikolova et al. 2020).

In temperate forest ecosystems, roughly $50 \%$ of total net primary productivity are allocated below ground (Newman et al. 2006), from which a share of about $30 \%$ is invested into newly formed roots under unstressed conditions (Nadelhoffer and Raich 1992). Gross primary production of temperate deciduous forests is reported to range between 1000 and $3000 \mathrm{~g}$ carbon (C) $\mathrm{m}^{-2} \mathrm{y}^{-1}$ (Collalti and Prentice 2019). Fine root biomass of temperate deciduous forests ranges from 400 to $1100 \mathrm{~g} \mathrm{~m}^{-2}$ (Nadelhoffer and Raich 1992; Hertel et al. 2013) being equivalent to 220 to $600 \mathrm{~g} \mathrm{C}$ when calculating a $\mathrm{C}$ content of fine root biomass of $0.55 \mathrm{~g} \mathrm{~g}^{-1}$ (Terzaghi et al. 2013). Hence, a complete fine root turnover (100\% mortality and unchanged quantity of living roots) means that trees invest around $20 \%$ of their annual photosynthetic production into fine root biomass. Thus, in our study the $\mathrm{C}$-allocation into fine root biomass was likely to be in the order of $40 \%$ of annually fixed carbon, since over the entire observation period (from May to August) the fine-root turnover was very high. The share is probably even higher, because at the same time, drought causes a decline in leaf assimilation, which was reported to be $80 \%$ under water stress for $Q$. petraea in France (Epron et al. 1992). Since C-reserves are vital for coping with multiple stressors (Adams et al. 2017; Maguire and Kobe 2015), its depletion might threaten the prospective tree vitality in HFFs in a scenario of more consecutive droughts coming along with climate change.

Under usual precipitation conditions, fine root mortality was shown to be much lower in comparison to values that we found under drought. For instance, Eissenstat et al. (2000) showed fine root survivorship of at least $80 \%$ after 100 days after first appearance in sugar maple, and Wells and Eissenstat (2001) reported fine root mortality of 50\% only after more than 200 days after first appearance in apple, while we show mortality rates of $50 \%$ to $100 \%$ after approximately 40 days under drought.

\section{Fine root parameters vary by tree species}

Our results confirm our first hypothesis that elms had higher RAI and LRD than oaks in the top soil. However, this was only true for old and not for young trees. The contrast in species-specific root distribution patterns causing the difference in RAI and LRD between oaks and elms seem to become distinct only at mature ages. This contrast between old elms and oaks might be determined by a trade-off between deep and shallow root investment. Since below ground primary 
productivity of trees is C-limited, trees are not able to produce high root densities along whole soil profiles, but rather allocate their roots in particular soil layers or extend them to the deeper soil (e.g., Zhou et al. 2020). The difference in rooting strategies may result in site-specific and situational differences in the success of water uptake and nutrient capture. As U. laevis mostly allocate its roots in the upper soil (Kutschera and Lichtenegger 2002), low precipitation might result in insufficient water uptake of elms leading to xylem cavitation and the loss of hydraulic conductivity (Maherali et al. 2004), a major mortality risk for trees (Adams et al. 2017). However, xylem cavitation risk depends not only on the degree of water shortage, but also on structural differences of wood anatomy. One of those factors is xylem vessel diameter. This parameter is significantly higher (as we calculated using transversal sections from the wood anatomy atlas (Schweingruber 1990) in $Q$. robur (mean vessel diameter $0.21 \mathrm{~mm}$ ) than in $U$. laevis (mean vessel diameter $0.17 \mathrm{~mm}$ ). The larger vessels a tree has, the more vulnerable to xylem cavitation it is (Tyree and Zimmerman 2002). From this point of view, oaks having larger vessels than elms should have higher cavitation levels. On the other hand, Cuneo et al. (2016) showed that structural damage of fine root cortical cells provoked by drought disrupts the hydraulic continuum from soil to plant and leads to the unrecoverable xylem conductivity loss. From this point of view, elms having higher fine root mortality than oaks should have higher cavitation levels. To our knowledge, xylem conductivity loss of $U$. lae$v i s$ has not yet been studied in situ and, hence, a direct comparison with $Q$. robur regarding vulnerability to cavitation is not possible. However, a strong drought adaptation ability of Q. robur was reported by Mikac et al. (2018), while Venturas et al. (2013) in their studies on elm seedlings, characterize U. laevis to be highly vulnerable to cavitation. This might indicate what still needs to be evidenced by further studies: root distribution patterns are pivotal for fine root mortality, consequently, for cavitation risk and, thus, for survival of trees under progressive drought incidences.

\section{Tree age influences fine root parameters}

Our second hypothesis that old trees have a higher RAI and LRD than young trees was only partly confirmed: In contrast to our expectation, old oaks generally had lower RAI and LRD than young oaks and old elms only had higher RAI and LRD in the topsoil (Fig. 3). We assume that the sink strength of growing tap roots of old oaks lead to a limited allocation of assimilates to roots in the top soil, which explains the lower RAI and LRD of old compared to young oak trees. Elms allocating the major part of their roots in the top soil must reduce investment of resources into the deeper roots. In addition, differences in RAI and LRD between old and young trees could also be caused by an uneven distribution of fine roots around tree stems of trees of different ages. The quantity of tree roots may not be distributed homogenously in the soil and does not always show a linear decline with increasing distance to a tree stem (Leuschner et al. 2001; Mulia and Dupraz 2006). However, we suggest that a mistake due to unevenness of root distribution is not undermining our results, as our aim was not to quantify fine root turnover as precise as possible, but to measure the relative mortality of fine roots. If the mistake is indeed present, it should be equal for all samples taken.

In our study, RRM of old trees decreased while that of young trees increased during summer 2018 with increasing drought. In consequence, RRM was lower in old than in young trees in late summer (at a depth 10-20 cm). Similar results were reported for Prunus avium, where mortality of roots of old trees was also higher than that of young trees in autumn, but not in spring (Baddeley and Watson 2005).

The interactive effect of tree age and time of sampling on RRM was significant at both sampled soil depths. However, the prediction that RRM of old trees should generally be lower than that of young trees was not confirmed. We did not find significant main effects of tree age on RRM (Table 1). In contrast to our expectations, old trees generally had higher RRM than young trees. This is in agreement with results on fine root biomass in differently aged boreal forests in Finland and Canada with an increase of fine root necromass and fine root mortality with stand age (Makkonen and Helmisaari 2001; Yuan and Chen 2012). This phenomenon might be explained by the optimal allocation model of Trugman et al. (2018), showing that following severe drought the costs of restoration of xylem function are proportionally higher for large than for small trees. Thus, increased tree size oppose the recovery to a positive C-balance after drought, leading to a shortage of nonstructural carbon that may translate into higher mortality of fine roots.

We speculate that the difference in RRM dynamics of old and young trees can at least partly be caused by different rooting depths among trees of different ages and, therefore, by different ability to transport water from deep roots (reaching soil layers kept wet by capillary rise from the close groundwater) to shallow roots. Old trees of Pseudotsuga menziesii and Pinus ponderosa in Oregon, USA, showed higher capability to perform HR and were found to lose much less root hydraulic conductivity during drought than young trees (Domec et al. 2004). We suggest that old trees of oaks and elms in HFFs having deeper roots can redistribute water among their shallow fine roots keeping them alive also with increasing drought, while young trees do not have access to deeper and presumably wetter soil strata. However, to the best of our knowledge, there are no studies that have focused on HR in temperate HFFs. Meanwhile, our study suggests that hydraulically driven water transport from deep 
roots to shallow roots might play a role in fine root vitality in HFFs in the summer. Therefore, we advocate further studies on these processes in HFFs.

\section{RRM significantly changes during the summer, but RAI and LRD do not}

RAI and LRD were not decreasing during summer with increasing drought, as we expected with our third hypothesis. In a study of Büttner and Leuschner (1994), fine root biomass and surface area of $Q$. petraea did neither decrease during summer; however, here, fine root biomass peaked in August. A peak in fine root elongation in July and August was also found in forests dominated by Acer saccharum, Fagus grandifolia, Betula alleghaniensis, and Acer rubrum (Burke and Raynal 1994). According to our results, RAI and LRD did not significantly change during summer, showing neither a clear trend to increase nor to decrease. The high RRM rates suggest that constant RAI and LRD values during summer are due to high production rates of new root structures. Indeed, Ponti et al. (2004) showed a steady increase in fine root production during summer in $Q$. robur in Italy's lowland that probably allows trees to sustain the necessary amount of fine roots.

In our study, the amount of fine roots of oaks and elms did not change during summer in spite of an increase in drought conditions. Root biomass of $Q$. ilex did neither change significantly during summer with a strong increase of drought in the South of Italy, and the mean annual fine root necromass was higher than live biomass, probably, because trees invested many resources into the production of fine roots (Montagnoli et al. 2019). In our study, extreme high values of RRM also suggest that trees keep their amount of roots unchanged not by keeping alive the same roots during the whole summer, but due to an enormous root turnover. Overall, this means that oaks and elms were able to survive under severe drought conditions, because their C-balance allowed for the replacement of $50-100 \%$ of their fine roots lost due to drought.

We found that fine root dynamics differ between oaks and elms and between age classes of trees in the HFFs in a way that different vulnerabilities to future drought scenarios could be expected and should be accounted for by appropriate ecosystem management.

\section{Conclusions}

Our results showed that $Q$. robur and $U$. laevis keep the fine root biomass constant during summer drought. As old trees have deeper roots and consequently meet the structural requirements to perform $\mathrm{HR}$, this could be a plausible explanation that fine root mortality was lower than those of young trees. Elms allocate the major part of their fine roots in the top soil, and thus they are more vulnerable to mortality, and hence, as plausible consequence, to cavitation. Under severe drought, trees invest a lot into the production of new fine roots. As a big part of resources is used up for this, the long-term survival chances of trees in HFFs can be reduced, especially, under stronger and more frequent droughts in the future. We assume that the equilibrium between old and young trees should be considered in management plans for HFFs to allow tree-mediated hydraulic integration processes to contribute to root vitality of trees in HFFs.

Author contribution statement $\mathrm{AL}$ did fine root analysis and wrote the first draft; $\mathrm{AH}$ and LKVN did soil analysis; $\mathrm{KJ}$ and CR provided the conceptual framework of the study, supervised the data analysis and worked on the manuscript.

Supplementary Information The online version contains supplementary material available at https://doi.org/10.1007/s00468-022-02275-3.

Acknowledgements We thank Prof. Dr. Christoph Leuschner, Mechthild Stange, Eva Messinger and other staff working in the Plant Ecology and Ecosystems Research of Georg-August-Universität Göttingen for sharing the experience in methods of fine root analysis. We are grateful to field assistant Diana Richter and to all MediAN colleagues.

Funding Open Access funding enabled and organized by Projekt DEAL. This research is a part of the project MediAN (Mechanismen der Ökosystemdienstleistungen von Hartholz-Auenwäldern: Wissenschaftliche Analyse sowie Optimierung durch Naturschutzmanagement). This study was funded by the Bundesministerium für Bildung und Forschung (BMBF 01LC1601A).

Availability of data and materials The data is available in Knowledge Network for Biocomplexity: https://knb.ecoinformatics.org/view/urn\% 3Auuid\%3A7106c352-ae67-4ef9-a55f-fafe13c6b827

Code availability Not applicable.

\section{Declarations}

Conflict of interest The authors declare that they have no conflict of interests.

Open Access This article is licensed under a Creative Commons Attribution 4.0 International License, which permits use, sharing, adaptation, distribution and reproduction in any medium or format, as long as you give appropriate credit to the original author(s) and the source, provide a link to the Creative Commons licence, and indicate if changes were made. The images or other third party material in this article are included in the article's Creative Commons licence, unless indicated otherwise in a credit line to the material. If material is not included in the article's Creative Commons licence and your intended use is not permitted by statutory regulation or exceeds the permitted use, you will need to obtain permission directly from the copyright holder. To view a copy of this licence, visit http://creativecommons.org/licenses/by/4.0/. 


\section{References}

Adams HD, Zeppel MJB, Anderegg WRL, Hartmann H, Landhäusser SM, Tissue DT et al (2017) A multi-species synthesis of physiological mechanisms in drought-induced tree mortality. Nat Ecol Evol 1(9):1285-1291. https://doi.org/10.1038/s41559-017-0248-x

Auenzustandsbericht. Bundesministerium für Umwelt, Naturschutz und Reaktorsicherheit. https://www.bfn.de/fileadmin/BfN/wasser/Dokumente/AZB_2021/AZB_2021_bf.pdf. Accessed 21 April 2021

Baddeley JA, Watson CA (2005) Influences of root diameter, tree age, soil depth and season on fine root survivorship in Prunus avium. Plant Soil 276(15):15-22. https://doi.org/10.1007/ s11104-005-0263-6

Bouma TJ, Bryla DR (2000) On the assessment of root and soil respiration for soils of different textures: interactions with soil moisture contents and soil $\mathrm{CO}_{2}$ concentrations. Plant Soil 227:215-221. https://doi.org/10.1023/A:1026502414977

Burke MK, Raynal DJ (1994) Fine root growth phenology, production, and turnover in a northern hardwood forest ecosystem. Plant Soil 162:135-146. https://doi.org/10.1007/BF01416099

Büttner V, Leuschner C (1994) Spatial and temporal patterns of fine root abundance in a mixed oak-beech forest. For Ecol Manage 70(1-3):11-21

Cierjacks A, Kleinschmit B, Babinsky M, Kleinschroth F, Markert A, Menzel M, Ziechmann U, Schiller T, Graf M, Lang F (2010) Carbon stocks of soil and vegetation on Danubian floodplains. J Plant Nutr Soil Sci 173:644-653. https://doi.org/10.1002/jpln. 200900209

Collalti A, Prentice IC (2019) Is NPP proportional to GPP? Waring's hypothesis 20 years on. Tree Physiol 39(8):1473-1483. https:// doi.org/10.1093/treephys/tpz034

Cuneo IF, Knipfer T, Brodersen CR, McElrone AJ (2016) Mechanical failure of fine root cortical cells initiates plant hydraulic decline during drought. Plant Physiol 172(3):1669-1678. https://doi.org/10.1104/pp.16.00923

Deutscher Wetterdienst. https://opendata.dwd.de/. Accessed 21 April 2021

Deutsches Gewässerkundliches Jahrbuch. Elbegebiet, Teil III. Untere Elbe ab der Havelmündung 2014. http://www.dgj.de/docs/eiii_ 2014.pdf. Accessed 18 March 2021

Domec J-C, Warren JM, Meinzer FC, Brooks JR, Coulombe R (2004) Native root xylem embolism and stomatal closure in stands of Douglas-fir and ponderosa pine: mitigation by hydraulic redistribution. Oecologia 141:7-16. https://doi.org/10.1007/ s00442-004-1621-4

Domec J-C, Ogée J, Noormets A, Jouangy J, Gavazzi M, Treasure E, Sun G, McNulty SG, King JS (2012) Interactive effects of nocturnal transpiration and climate change on the root hydraulic redistribution and carbon and water budgets of southern United States pine plantations. Tree Physiol 32:707-723. https://doi. org/10.1093/treephys/tps018

Edwards NT, Harris WF (1977) Carbon cycling in a mixed deciduous forest floor. Ecology 58:431-437. https://doi.org/10.2307/ 1935618

Eissenstat DM, Wells CE, Yanai RD, Whitbeck JL (2000) Building roots in a changing environment: implications for root longevity. New Phytol 147:33-42. https://doi.org/10.1046/j.1469-8137. 2000.00686.x

Epron D, Dreyer E, Bréda N (1992) Photosynthesis of oak trees [Quercus petraea (Matt.) Liebl.] during drought under field conditions: diurnal course of net $\mathrm{CO}_{2}$ assimilation and photochemical efficiency of photosystem II. Plant Cell Environ 15:809-820. https://doi.org/10.1111/j.1365-3040.1992.tb02148.x
Gallardo A (2003) Spatial variability of soil properties in a floodplain forest in Northwest Spain. Ecosystems 6:564-576. https:// doi.org/10.1007/s10021-003-0198-9

Gaul D, Hertel D, Borken W, Matzner E, Leuschner C (2008) Effects of experimental drought on the fine root system of mature Norway spruce. For Ecol Manage 256(5):1151-1159. https://doi. org/10.1016/j.foreco.2008.06.016

Hafner BD, Tomasella M, Häberle KH, Goebel M, Matyssek R, Grams TEE (2017) Hydraulic redistribution under moderate drought among English oak, European beech and Norway spruce determined by deuterium isotope labeling in a split-root experiment. Tree Physiol 37(7):950-960. https://doi.org/10. 1093/treephys/tpx050

Hafner BD, Hesse BD, Bauerle TL, Grams TEE (2019) Water potential gradient, root conduit size and root xylem hydraulic conductivity determine the extent of hydraulic redistribution in temperate trees. Funct Ecol 34(3):561-574. https://doi.org/10. $1111 / 1365-2435.13508$

Heger A, Becker JN, Vásconez Navas LK, Eschenbach A (2021) Factors controlling soil organic carbon stocks in hardwood floodplain forests of the lower middle Elbe River. Geoderma 404115389. https://doi.org/10.1016/j.geoderma.2021.115389

Hendrick RL, Pregitzer KS (1996) Temporal and depth-related patterns of fine root dynamics in northern hardwood forests. J Ecol 84(2):167-176. https://doi.org/10.2307/2261352

Hendricks JJ, Nadelhoffer KJ, Aber JD (1993) Assessing the role of fine roots in carbon and nutrient cycling. Trends Ecol Evol 8:174-178. https://doi.org/10.1016/0169-5347(93)90143-D

Hertel D, Leuschner C (2002) A comparison of four different fine root production estimates with ecosystem carbon balance data in a Fagus-Quercus mixed forest. Plant Soil 239(2):237-251. https://doi.org/10.1023/A:1015030320845

Hertel D, Strecker T, Müller-Haubold H, Leuschner C (2013) Fine root biomass and dynamics in beech forests across a precipitation gradient - is optimal resource partitioning theory applicable to water-limited mature trees? J Ecol 101(5):1183-1200. https:// doi.org/10.1111/1365-2745.12124

IUSS Working Group WRB (2015) World Reference Base for Soil Resources 2014, Update 2015: International soil classification system for naming soils and creating legends for soil maps, (Vol. 106) FAO, Rome

Jackson RB, Mooney HA, Schulze ED (1997) A global budget for fine root biomass, surface area, and nutrient contents. Proc Natl Acad Sci USA 94:7362-7366. https://doi.org/10.1073/pnas.94. 14.7362

Kern CC, Friend AL, Johnson JMF, Coleman MD (2004) Fine root dynamics in a developing Populus deltoides plantation. Tree Physiol 24(6):651-660. https://doi.org/10.1093/treephys/24.6.651

Klimo E, Hager H (2001) The floodplain forests in Europe: current situation and perspectives. Leiden, Boston, Köln, Brill

Konôpka B, Noguchi K, Sakata T, Takahashi M, Konôpková Z (2007) Effects of simulated drought stress on the fine roots of Japanese cedar (Cryptomeria japonica) in a plantation forest on the Kanto Plain, eastern Japan. J for Res 12(2):143-151. https://doi.org/10. 1007/s10310-006-0257-0

Kutschera L, Lichtenegger E (2002) Wurzelatlas mitteleuropäischer Waldbäume und Sträucher. Stocker, Graz

Leuschner C, Hertel D, Coners H, Büttner V (2001) Root competition between beech and oak: a hypothesis. Oecologia 126:276-284. https://doi.org/10.1007/s004420000507

Löpmeier F-J (1994) Berechnung der Bodenfeuchte und Verdunstung mittels agrarmeteorologischer Modelle. Zeitschrift Für Bewaesserungswirtschaft 29:157-167

Machar I, Hager H, Pechanec V, Kulhavy J, Mindas J (2020) Floodplain Forests - Key Forest Ecosystems for Maintaining and Sustainable Management of Water Resources in Alluvial Landscape. 
In: Zelenakova M, Negm AM, Fialova J (eds) Assessment and protection of water resources in the Czech Republic. Springer Water, pp 249-274

Maguire AJ, Kobe RK (2015) Drought and shade deplete nonstructural carbohydrate reserves in seedlings of five temperate tree species. Ecol Evol 5(23):5711-5721. https://doi.org/10.1002/ece3.1819

Maherali H, Pockman WT, Jackson RB (2004) Adaptive variation in the vulnerability of woody plants to xylem cavitation. Ecology 85(8):2184-2199. https://doi.org/10.1890/02-0538

Makkonen K, Helmisaari HS (2001) Fine root biomass and production in Scots pine stands in relation to stand age. Tree Physiol 21(2-3):193-198. https://doi.org/10.1093/treephys/21.2-3.193

Marshall JD (1986) Drought and shade interact to cause fine-root mortality in Douglas-fir seedlings. Plant Soil 91(1):51-60. https://doi. org/10.1007/BF02181818

Matamala R, Gonzalez-Meler MA, Jastrow JD, Norby RJ, Schlesinger WH (2003) Impacts of fine root turnover on forest NPP and soil C sequestration potential. Science 302:1385-1387. https://doi.org/ 10.1126/science. 1089543

McClaugherty CA, Aber JD, Melillo JM (1982) The role of fine roots in the organic matter and nitrogen budgets of two forested ecosystems. Ecology 63(5):1481-1490. https://doi.org/10.2307/1938874

McCormack ML, Dickie IA, Eissenstat DM, Fahey TJ, Fernandez CW, Guo D, Helmisaari HS, Hobbie EA, Iversen CM, Jackson RB, Leppälammi-Kujansuu J, Norby RJ, Phillips RP, Pregitzer KS, Pritchard SG, Rewald B, Zadworny M (2015) Redefining fine roots improves understanding of belowground contributions to terrestrial biosphere processes. New Phytol 207:505-518. https:// doi.org/10.1111/nph.13363

Meier IC, Leuschner C (2008) Belowground drought response of European beech: fine root biomass and carbon partitioning in 14 mature stands across a precipitation gradient. Glob Change Biol 14:2081-2095. https://doi.org/10.1111/j.1365-2486.2008.01634.x

Meinzer FC, Brooks JR, Bucci S, Goldstein G, Scholz FG, Warren JM (2004) Converging patterns of uptake and hydraulic redistribution of soil water in contrasting woody vegetation types. Tree Physiol 24(8):919-928. https://doi.org/10.1093/treephys/24.8.919

Mikac S, Zmegač A, Trlin D, Paulić V, Oršanić M, Anić I (2018) Drought-induced shift in tree response to climate in floodplain forests of Southeastern Europe. Sci Rep 8(1):660. https://doi.org/ 10.1038/s41598-018-34875-w

Montagnoli A, Dumroeseb RK, Terzaghi M, Onellic E, Scippad GS, Chiatantea D (2019) Seasonality of fine root dynamics and activity of root and shoot vascular cambium in a Quercus ilex $\mathrm{L}$. forest (Italy). For Ecol Manage 431:26-34. https://doi.org/10.1016/j. foreco.2018.06.044

Mulia R, Dupraz C (2006) Unusual fine root distributions of two deciduous tree species in southern France: What consequences for modelling of tree root dynamics? Plant Soil 281:71-85. https:// doi.org/10.1007/s11104-005-3770-6

Nadelhoffer KJ, Raich JW (1992) Fine root production estimates and belowground carbon allocation in forest ecosystems. Ecology 73(4):1139-1147. https://doi.org/10.2307/1940664

Neumann RB, Cardon ZG (2012) The magnitude of hydraulic redistribution by plant roots: a review and synthesis of empirical and modeling studies. New Phytol 194(2):337-352. https://doi.org/10. 1111/j.1469-8137.2012.04088.x

Newman GS, Arthur MA, Muller RN (2006) Above- and belowground net primary production in a temperate mixed deciduous forest. Ecosystems 9(3):317-329. https://doi.org/10.1007/ s10021-006-0015-3

Nikolova PS, Bauerle TL, Häberle K-H, Blaschke H, Brunner I, Matyssek R (2020) Fine-root traits reveal contrasting ecological strategies in European Beech and Norway Spruce during extreme drought. Front Plant Sci 11:1211. https://doi.org/10.3389/fpls. 2020.01211
Ponti F, Minotta G, Cantoni L, Bagnaresi U (2004) Fine root dynamics of pedunculate oak and narrow-leaved ash in a mixed-hardwood plantation in clay soils. Plant Soil 259:39-49. https://doi.org/10. 1023/B:PLSO.0000020949.61458.76

Pregitzer KS, Kubiske ME, Yu CK, Hendrick RL (1997) Relationships among root branch order, carbon, and nitrogen in four temperate species. Oecologia 111:302-308. https://doi.org/10.1007/s0044 20050239

Reich PB (2014) The world-wide 'fast-slow' plant economics spectrum: a traits manifesto. J Ecol 102:275-301. https://doi.org/10. $1111 / 1365-2745.12211$

Richter AK, Hajdas I, Frossard E, Brunner I (2013) Soil acidity affects fine root turnover of European beech. Plant Biosyst Int J Deal All Aspects Plant Biol 147(1):50-59. https://doi.org/10.1080/11263 504.2012.742471

Schindler S, O’Neill FH, Biró M, Damm C, Gasso V, Kanka R, van der Sluis T, Krug A, Lauwaars SG, Sebesvari Z, Pusch M, Baranovsky B, Ehlert T, Neukirchen B, Martin JR, Euller K, Mauerhofer V, Wrbka T (2016) Multifunctional floodplain management and biodiversity effects: a knowledge synthesis for six European countries. Biodivers Conserv 25(7):1349-1382. https:// doi.org/10.1007/s10531-016-1129-3

Schweingruber FH (1990) Anatomie europäischer Hölzer. Ein Atlas zur Bestimmung europäischer Baum-, Strauch- und Zwergstrauchhölzer (Anatomy of European woods). Verlag Haupt, Bern, Stuttgart

Shupe HA, Hartmann T, Scholz M, Jensen K, Ludewig K (2021) Carbon stocks of hardwood floodplain forests along the middle elbe: the influence of forest age, structure, species, and hydrological conditions. Water 13(5):670. https://doi.org/10.3390/w13050670

Stojanović DB, Levanič T, Matović B, Orlović S (2015) Growth decrease and mortality of oak floodplain forests as a response to change of water regime and climate. Eur J for Res 134(3):555567. https://doi.org/10.1007/s10342-015-0871-5

Terzaghi M, Montagnoli A, Di Iorio A, Scippa GS, Chiatante D (2013) Fine-root carbon and nitrogen concentration of European beech (Fagus sylvatica L.) in Italy Prealps: possible implications of coppice conversion to high forest. Front Plant Sci 4:192. https://doi. org/10.3389/fpls.2013.00192

Thomsen S, Reisdorff C, Gröngröft A, Jensen K, Eschenbach A (2020) Responsiveness of mature oak trees (Quercus robur L.) to soil water dynamics and meteorological constraints in urban environments. Urban Ecosyst 23:173-186. https://doi.org/10.1007/ s11252-019-00908-z

TIBCO Software Inc., 13 (2017) http://statistica.io

Tockner K, Stanford JA (2002) Riverine flood plains: present state and future trends. Environ Conserv 29(3):308-330. https://doi.org/10. 1017/S037689290200022X

Trugman AT, Detto M, Bartlett MK, Medvigy D, Anderegg WRL, Schwalm C, Schaffer B, Pacala SW (2018) Tree carbon allocation explains forest drought-kill and recovery patterns. Ecol Lett 21(10):1552-1560. https://doi.org/10.1111/ele.13136

Tyree MT, Zimmerman MH (2002) Xylem structure and the ascent of sap. Springer-Verlag, New York

Van Hees AFM (1997) Growth and morphology of pedunculate oak (Quercus robur $\mathrm{L}$ ) and beech (Fagus sylvatica $\mathrm{L}$ ) seedlings in relation to shading and drought. Ann for Sci 54(1):9-18. https:// doi.org/10.1051/forest:19970102

Venturas M, López R, Gascó A, Gil L (2013) Hydraulic properties of European elms: xylem safety-efficiency tradeoff and species distribution in the Iberian Peninsula. Trees 27(6):1691-1701. https:// doi.org/10.1007/s00468-013-0916-7

Wells CE, Eissenstat DM (2001) Marked differences in survivorship among apple roots of different diameters. Ecology 82:882-892. https://doi.org/10.1890/0012-9658(2001)082[0882:MDISAA] 2.0.CO;2 
Yuan ZY, Chen HYH (2010) Fine root biomass, production, turnover rates, and nutrient contents in boreal forest ecosystems in relation to species, climate, fertility, and stand age: literature review and meta-analyses. Crit Rev Plant Sci 29(4):204-221. https://doi.org/ 10.1080/07352689.2010.483579

Yuan ZY, Chen HYH (2012) Fine root dynamics with stand development in the boreal forest. Funct Ecol 26(4):991-998. https://doi. org/10.1111/j.1365-2435.2012.02007.x

Zhou Y, Wigley BJ, Case MF, Coetsee C, Staver AC (2020) Rooting depth as a key woody functional trait in savannas. New Phytol 227:1350-1361. https://doi.org/10.1111/nph.16613
Publisher's Note Springer Nature remains neutral with regard to jurisdictional claims in published maps and institutional affiliations. 